\title{
Striking a balance: resolving conflicts between the duty of confidentiality and duties to third parties in genetics
}

\author{
Naomi Hawkins* and Timon Hughes-Davies ${ }^{\dagger}$ \\ University of Exeter Law School, University of Exeter, Exeter, UK \\ *Corresponding author. Email: n.l.hawkins@exeter.ac.uk
}

(Accepted 31 October 2017)

\begin{abstract}
Genetic information is relevant not only to the patient, but also to their family. Where a patient refuses to share that information with family members, then their legal rights may conflict. This paper focuses on that conflict between the rights of individuals and the rights of third parties. We first examine the nature of the duty of confidence as it applies in these circumstances, and the extent to which it can appropriately accommodate the familial nature of genetic information. We then consider the situations in which a healthcare practitioner might owe a third-party family member a tortious duty of care. We conclude that in most cases, there will be no duty owed to third parties, but that in certain limited circumstances, a duty of care should arise.
\end{abstract}

Keywords: tort; duty of care; confidentiality; medical law

\section{Introduction}

Medical confidentiality in the context of genetics raises interesting tensions because the information in question is not only relevant to an individual patient, but also to family members. The information is more relevant to relatives closer in degree, and the chance of it being relevant reduces the further away in the family tree the relative is from the original patient. It is possible that the interests of the patient and the family member may conflict - such as where a patient does not wish to share genetic information with a family member - but where that information might allow that family member to obtain a diagnosis and take action to avoid a negative outcome. Such a situation raises important and interesting legal questions, which have been reinvigorated by recent case law. ${ }^{1}$

In $A B C v$ St George's, ${ }^{2}$ the claimant argued that a healthcare practitioner (HCP) who had failed to disclose genetic information to a family member was liable to that family member in negligence. The Court of Appeal allowed an appeal from the High Court, which had struck out the claim as having no reasonable cause of action at a preliminary hearing before trial. ${ }^{3}$ The claim may now be tried, and it will be for the lower court to determine if an HCP has a legal duty to disclose genetic information to

\footnotetext{
${ }^{\dagger}$ The authors are grateful to Professor Anneke Lucassen, Dr Daniele Carrieri, Dr Sandi Dheensa and the Recontacting in Mainstreaming Genetics project team, Professor Andrea Lista, Professor Charlotte Waelde, Professor Christian Witting, Dr Paula Boddington and members of the Science, Culture and the Law research group at the University of Exeter Law School for comments on earlier drafts of this paper. Naomi Hawkins is supported by the ESRC (grant codes ES/K009575/1 and $\mathrm{ES} / \mathrm{L} 002868 / 1)$.

${ }^{1}$ ABC v St George's Healthcare NHS Trust [2015] EWHC 1394 (QB); Smith v University Hospitals of Leicester NHS Trust [2016] EWHC 817 (QB).

${ }^{2}$ [2017] EWCA Civ 336.

${ }^{3} A B C v$ St George's Healthcare NHS Trust, above $\mathrm{n} 1$.

( $)$ The Society of Legal Scholars 2018. This is an Open Access article, distributed under the terms of the Creative Commons Attribution licence (http://creativecommons.org/licenses/by/4.0/), which permits unrestricted re-use, distribution, and reproduction in any medium, provided the original work is properly cited.
} 
any family member of their patient. It is our contention that a blunt exclusion of any duty in all circumstances pushes the balance of rights too far in the direction of the maintenance of confidentiality. As a result of this approach, an HCP would be well advised to maintain confidentiality in all circumstances, notwithstanding ethical arguments in favour of disclosure, as they will never be liable for failure to disclose to a third party, but could be liable for breach of confidence. This, in our view, is problematic.

In this paper we focus on the conflicts between the rights of individuals and the rights of third parties. ${ }^{4}$ We first examine the nature of the duty of confidence as it applies in these circumstances, and the extent to which it can appropriately accommodate the familial nature of genetic information. We then consider the situations in which an HCP might owe a third party family member a tortious duty of care. We conclude that in most cases, there will be no duty owed to third parties, but that in certain limited circumstances, a duty of care should arise. We argue that controls on liability can better be imposed by consideration of breach, rather than by imposing a blanket exclusion of all duties of care.

This is a paper focused primarily on the law of confidence and duty of care to third parties in genetics, more than ethical and professional obligations. Although the bioethics literature informs the law in important respects, and is relevant to our analysis, our discussions are mainly focused on the legal position, rather than the moral or ethical argumentation. Moreover, we integrate an exploration of the duty of confidence and the law of tort as it applies in this field, in the light of recent scientific and case law developments.

\section{Genetic information and the family}

As has been extensively rehearsed elsewhere, ${ }^{5}$ unlike many other types of information, genetic information is not only relevant to the individual patient, but also to family members. There are many diseases which have some genetic component. Heart disease and cancer 'run in families', and can arise from different genetic and environmental causes. ${ }^{6}$ However, the types of diseases with which this paper is concerned have a much stronger and more clearly defined genetic basis.

Single gene disorders involve mutations in a single gene that lead to a disease state, for example Huntington's disease or cystic fibrosis. ${ }^{7}$ Most single gene disorders are rare. ${ }^{8}$ An autosomal dominant disorder is a genetic disease which will manifest itself if an individual possesses at least one affected copy of the relevant gene, with a 50\% risk that offspring will inherit the mutation from the affected parent. Many autosomal dominant disorders either have a delayed age of onset or exhibit reduced penetrance, that is, there is not a $100 \%$ chance that the person will exhibit symptoms of the disease

\footnotetext{
${ }^{4}$ We limit our consideration in this paper to the rights and duties arising in the clinical context, and therefore do not consider the duties which might arise where a participant takes part in research, or where non-clinical genetic testing is undertaken (such as direct-to-consumer testing for interest or ancestry testing). It is worth noting, however, that the clear distinctions which may in the past have been possible between research and clinical testing may be increasingly blurred, especially in the field of 'precision medicine'. These questions are discussed in C Mitchell et al 'Exploring the potential duty of care in clinical genomics under UK law' (2017) 17(3) Medical Law International 158.

${ }^{5}$ See for example SM Liao 'Is there a duty to share genetic information?' (2009) 35 Journal of Medical Ethics 306; M Parker and AM Lucassen 'Genetic information: a joint account?' (2004) 329 British Medical Journal 165; GT Laurie 'Obligations arising from genetic information - negligence and the protection of familial interests' (1999) 11 Child and Family Law Quarterly 97; BM Knoppers 'Genetic information and the family: are we our brother's keeper?' (2002) 20 Trends in Biotechnology 85.

${ }^{6}$ HV Firth, JA Hurst and JG Hall Oxford Desk Reference: Clinical Genetics (Oxford: Oxford University Press, 2005$) 24$.

${ }^{7} \mathrm{~A}$ catalogue of all known single-gene disorders was compiled in 1966 by Victor McKusick, and an up-to-date version is now available: V McKusick 'Online mendelian inheritance in man (OMIM)' http://www.omim.org/ (last accessed 9 July 2018).

${ }^{8}$ Single gene disorders range from relatively common genetic disorders such as cystic fibrosis with an incidence of about 1 in 2400 live births in the UK population: JA Dodge et al 'Cystic fibrosis mortality and survival in the UK: 1947-2003' (2007) 29 Eur Respiratory J 522, to extremely rare disorders which might have an incidence of perhaps 1 or even fewer in all births in a year in the UK.
} 
in question. ${ }^{9}$ An autosomal recessive disorder is a disorder which requires two affected copies of the gene to manifest clinically. When an individual concerned possesses only one of two affected copies of the gene, they are a carrier, and they do not manifest the disease, or will have very mild symptoms in comparison with the disease state. ${ }^{10}$ An $\mathrm{X}$-linked disorder is one which is inherited via the $\mathrm{X}$ chromosome, and may be either dominant or recessive. An X-linked dominant disorder manifests very severely in males, and often leads to spontaneous loss of an affected pregnancy or neonatal death; females have less severe features than males. An X-linked recessive disorder is encoded on the $\mathrm{X}$ chromosome such that a female who possesses one normal copy and one affected copy of the gene will not manifest the disease (although may have some minor features of the condition), but a male ${ }^{11}$ if he inherits the affected copy of the gene, will manifest the disease. ${ }^{12}$

This classification of diseases is something of an oversimplification. Not all disease genes are fully penetrant, and there may be variable severity in how a disease manifests in different individuals who all carry the same mutation, even within families. Moreover, later onset diseases may have an earlier or later age of onset, and there are myriad genetic and environmental factors which influence disease course. Genetic inheritance is complex, and research continues in an attempt to further elucidate disease inheritance mechanisms. ${ }^{13}$

As may be evident from this short recital of genetic disease mechanisms, while the genetic information of an individual diagnosed with a genetic disease (the proband) may also be relevant to members of his or her family, the extent to which that information is relevant will vary depending on factors such as the closeness of the relationship (eg first degree relatives versus more distant relationships) as well as the nature of the disease (dominant versus recessive, penetrance, likelihood of spontaneous mutation causing the disease). It is therefore an oversimplification to contend that all genetic information is equally relevant to all the family of the proband - there is a degree of nuance. However, what is clear is that where a proband has been diagnosed with a genetic disease, then members of his or her family may have an increased risk of themselves having that genetic mutation and therefore the disease. HCPs working in the field of clinical genetics are therefore very concerned to disseminate the information through the family.

In many cases, where family relationships are reasonably cordial, there is no conflict between any duty to warn third parties and the duty of confidentiality, where the patient is prepared to disclose information, or gives permission for an HCP to disclose information to family members. ${ }^{14}$ Where, however, a patient refuses permission to disclose, as in the case of $A B C,{ }^{15}$ then a conflict between the duty of confidentiality, and any potential duty to third parties may arise. Although such cases may be relatively rare in practice, perhaps partly due to the care with which genetics professionals manage family communications, ${ }^{16}$ they nonetheless present an interesting legal question which

\footnotetext{
${ }^{9}$ Firth, Hurst and Hall, above n 6, p 6.

${ }^{10}$ Firth, Hurst and Hall, above n 6, p 8.

${ }^{11}$ Males possess only one $\mathrm{X}$ chromosome.

${ }^{12}$ Health Education England Genomics Education Programme 'X-linked recessive inheritance' <http://www.genomicseducation.hee.nhs.uk/modes-of-inheritance/x-linked-conditions/> accessed 18 July 2018.

${ }^{13}$ See for example the research into genetic variation arising from the ExAC project, available at http://exac.broadinstitute. org/, discussed in E Check Hayden 'A radical revision of human genetics' (2016) 538 Nature 154.

${ }^{14} \mathrm{We}$ acknowledge that cases of passive non-disclosure exist, where a patient undertakes to disclose to family members, and then does not. There are many and varied reasons and patterns of this non-disclosure. For an examination of the complexities of this area see M Arribas-Ayllon, K Featherstone and P Atkinson 'The practical ethics of genetic responsibility: non-disclosure and the autonomy of affect' (2011) 9 Soc Theory Health 3. However, for the purposes of this paper, we focus on the situation where an HCP is aware of a patient's intention not to disclose, in order to clearly examine the relevant legal principles. It may be worth noting, however, that an HCP who acts reasonably and who is unaware of a failure to disclose is unlikely to be liable in tort, and is similarly unlikely to choose to seek to disclose to a third party in spite of the duty of confidence.

${ }^{15} A B C v$ St George's Healthcare NHS Trust, above $\mathrm{n} 1$.

${ }^{16}$ A Clarke et al 'Genetic professionals' reports of nondisclosure of genetic risk information within families' (2005) 13 European Journal of Human Genetics 556. It may be worth noting that, while known cases of refusal to disclose may be
} 
demonstrates the need for the law to develop in a flexible and appropriate manner to accommodate emerging medical technologies. Moreover, as genomic medicine becomes integrated into mainstream clinical practice, it seems likely that the number of these cases will increase.

\section{Recent case law}

Two recent cases have provided the first English cases which are relevant to the question of confidentiality and the duty to warn in the context of genetic testing. In both, the claim was brought by a relative of the proband who had suffered damage as a result of the failure of the treating HCP to inform of the possibility of inheritance of a specific genetic condition.

\section{$A B C$ v St George's}

ABC $v$ St George's Healthcare NHS Trust, ${ }^{17}$ involved unusual facts: in 2007, the claimant's father killed the claimant's mother. He was convicted of manslaughter on the grounds of diminished responsibility and detained under the Mental Health Act 1983. ${ }^{18}$ In 2009, he was diagnosed with Huntington's disease. At the time, the claimant, who was pregnant, was attending family therapy sessions, with her father and therapists from the first defendant, St George's Healthcare NHS Trust. Sessions took place both before and after the father's diagnosis was confirmed.

The father did not want his daughters to be informed of his diagnosis: he was concerned that they 'might get upset, kill themselves or have an abortion'. ${ }^{19}$ Following discussion, the medical staff decided to respect his confidentiality: the claimant was not informed and her pregnancy continued. In 2013, the claimant tested positive for the Huntington's Disease gene. ${ }^{20}$

A claim was brought in negligence: it was argued that the defendants owed a duty to warn the claimant and that, by failing to disclose her father's diagnosis, the defendant had been in breach of that duty. The breach had caused damage, in that the claimant was denied the opportunity to terminate the pregnancy. ${ }^{21}$ The defendants applied to have the claim struck out, as having no reasonable cause of action. In the High Court, Nicol J found that it would not be 'fair, just and reasonable' to find that the defendants owed the claimant a duty of care; ${ }^{22}$ and that the duty claimed would involve a 'giant step', ${ }^{23}$ contrary to the incremental approach ${ }^{24}$ emphasised in Michael $v$ Chief Constable of South Wales Police. ${ }^{25}$ Accordingly, the application succeeded.

The Court of Appeal allowed an appeal: ${ }^{26}$ Irwin LJ, giving the only judgment, applied the Caparo ${ }^{27}$ test of proximity, foreseeability and whether it would be 'fair, just and reasonable' to impose a duty of

rare, HCPs worry that they do not know for certain whether a patient's expressed intention to disclose information to family members results in appropriate disclosure: S Dheensa, A Fenwick and A Lucassen 'Approaching confidentiality at a familial level in genomic medicine: a focus group study with healthcare professionals' (2017) BMJ Open 7:e012443.

${ }^{17}$ ABC v St George's Healthcare NHS Trust, above $\mathrm{n} 1$.

${ }^{18}$ Under the Mental Health Act 1983, ss 37 and 41.

${ }^{19} A B C v$ St George's Healthcare NHS Trust, above $\mathrm{n} 1$, at [5].

${ }^{20}$ It was not known at the time of the hearing whether her daughter had inherited the gene, as predictive testing for adult onset conditions is generally not carried out in children: JR Botkin et al 'Points to consider: ethical, legal, and psychosocial implications of genetic testing in children and adolescents' (2015) 97 The American Journal of Human Genetics 6.

${ }^{21}$ The court was prepared to accept, for the purposes of the application, that such a claim could have succeeded, had the defendant owed a duty of case. However, the claimant would have faced significant barriers, including establishing that the defendant's breach had caused actionable harm: see V Chico 'Non-disclosure of genetic risks: the case for developing legal wrongs' (2016) 16 Medical Law International 3.

${ }^{22}$ ABC $v$ St George's Healthcare NHS Trust, above $\mathrm{n} 1$, at [31].

${ }^{23} A B C v$ St George's Healthcare NHS Trust, above n 1, at [27].

${ }^{24}$ 'The development of the law of negligence has been by an incremental process rather than giant steps' Michael $v$ Chief Constable of South Wales Police [2015] UKSC 2, [2015] AC 1732 at [102] (Lord Toulson, with whom Lords Neuberger, Mance, Reed and Hodge agreed).

${ }^{25}$ Michael $v$ Chief Constable of South Wales Police [2015] UKSC 2, [2015] AC 1732.

${ }^{26}$ Above $\mathrm{n} 2$.

${ }^{27}$ Caparo Industries plc v Dickman [1990] 2 AC 605. 
care. Assuming, for the purposes of the application, that the elements of proximity and foreseeability had been made out, he considered the nine reasons that the defendant had set out that it would not be 'fair, just and reasonable' to impose a duty to disclose confidential genetic information.

The reasons included that the interest of the third party in receiving the information was a private interest that could not prevail over the public interest in maintaining confidentiality; that it would encourage HCPs to disclose when not justified; that the HCP would be subject to conflicting duties of confidentiality to the patient and disclosure to the third party; that it would undermine trust in HCPs and discourage patients from disclosing information; that it would cause HCPs to put undue pressure on patients to consent to disclosure; that it might be damaging to the third party's mental health to receive the information; and that it would place an additional burden on HCPs which would distract them from their role in treating patients.

The court noted that an HCP in possession of genetic information which affected a third party would, in some circumstances, be under an existing professional, as opposed to legal, obligation to disclose. The conflict between the duty of confidence to the patient and a professional obligation to prevent harm to others already existed and it was not established that to make the professional obligation legally binding would cause the problems claimed. Accordingly, none of the policy considerations was sufficiently powerful to justify allowing the claim to be struck out before trial. ${ }^{28}$ Furthermore, the Supreme Court had held, in Montgomery $v$ Lanarkshire Health Authority, ${ }^{29}$ that, in the case of informed consent, it was necessary to impose legal obligations to reinforce professional obligations, in order that HCPs would meet those obligations.

The Court of Appeal also considered the American cases of Tarasoff $f^{30}$ and Safer $v$ Pack, ${ }^{31}$ although it did not expressly endorse the cases. ${ }^{32}$ In both of these cases, it had been held that an HCP was, in some circumstances, under a duty to disclose confidential information to a third party. Of particular relevance was Safer: in this case, the plaintiff was the daughter of one of the defendant's patients, who had died of colo-rectal cancer in the 1950s. The plaintiff later suffered from the same condition, and claimed against the doctor for failing to warn her of her own risk of developing the disease. The Superior Court of New Jersey held that they saw 'no impediment, legal or otherwise, to recognising a physician's duty to warn those known to be at risk of avoidable harm from a genetically transmissible condition'. ${ }^{33}$

\section{Smith $v$ University of Leicester NHS Trust}

Following the successful strike out application in the High Court of $A B C$, a further claim in respect of a genetic disorder was brought in Smith $v$ University of Leicester NHS Trust. ${ }^{34}$ In this case, there was a failure to diagnose adrenomyeloneuropathy, a genetic disorder: the HCP ordered diagnostic tests but they were not carried out. As a result, the patient was not diagnosed until one of the claimants (his second cousin) was himself diagnosed with the childhood variant of the condition, adrenoleukodystrophy. The claim was against the HCP who failed to diagnose the condition at the earliest opportunity: had the earlier diagnosis been made, the claimants could have been tested at an earlier stage and taken steps to ameliorate their condition. As in $A B C$, the strike out application was granted: the court held that it would not be 'fair, just and reasonable' to impose a duty on an HCP in relation to a third party who was not a patient.

In this case, the reason that the relative was not informed was that the HCP had failed to diagnose the patient, rather than that the HCP was respecting the patient's refusal to consent to disclosure of his genetic information.

\footnotetext{
${ }^{28}$ ABC v St George's Healthcare NHS Trust, above n 1, at [26], [31], [34], [40]-[41] of the judgment.

${ }^{29}$ [2015] UKSC 11, [2015] AC 1430, at [93] (Lord Kerr and Lord Reed).

${ }^{30}$ Tarasoff $v$ Regents of the University of California (1976) 551 P2d 334.

${ }^{31}$ Safer $v$ Pack (1996) 291 NJ Sup 619, 677 A2d 1188.

${ }^{32} A B C$, above $\mathrm{n} 2$, at [60].

${ }^{33}$ Safer $v$ Pack, above n 31, at 1192.

${ }^{34}[2016]$ EWHC 817 (QB).
} 


\section{Competing duties?}

The nature of the English adversarial system is that cases tend to focus on either the question of the duty of confidence or the duty to warn. However, in the case of disclosure of genetic information to relatives against the wishes of the proband, the two duties are directly competing. We therefore examine the law relating to the duty of confidence, before considering the potential scope of the tortious duty to warn.

\section{Duty of confidence}

That a duty of confidence exists in relation to medical information is axiomatic. The traditional formulation of an equitable duty of confidence, with its three elements is: the information is of a private, personal or intimate nature; it is imparted in circumstances imposing an obligation of confidence; and it has been disclosed without authorisation. ${ }^{35}$

Case law since the introduction of the Human Rights Act 1998 has reformulated the cause of action in terms of private rather than confidential information, ${ }^{36}$ and the question is whether there is a 'reasonable expectation of privacy'. ${ }^{37}$ It is doubtful whether the reformulation of the test in light of the Human Rights Act 1998 has made any material difference in relation to the law applicable to medical information. Genetic information (at least insofar as it has medical implications) is private, ${ }^{38}$ and there is a reasonable expectation of privacy in relation to genetic information obtained or imparted in the medical context. The respect for the medical duty of confidentiality is well encapsulated by Lord Philips MR in Ashworth Security Hospital v MGN Ltd, who stated 'It is well settled that there is an abiding obligation of confidentiality as between doctor and patient, and in my view when a patient enters a hospital for treatment, whether he be a model citizen or murderer, he is entitled to be confident that details about his condition and treatment remain between himself and those who treat him' ${ }^{39}$ The case law of the European Court of Human Rights has equally upheld the importance of confidentiality of medical information under Article 8 of the European Convention on Human Rights (ECHR). Respecting the confidentiality of health data is a vital principle in the legal systems of all the contracting parties to the ECHR. ${ }^{40}$

Whilst the existence of the duty in a medical context is relatively uncontroversial, the flexibility of the test arises in relation to the question of breach. In such a case, a party needs to avail themselves of a legitimating reason for disclosure, typically either consent or the public interest. ${ }^{41}$

In the context of disclosure of genetic information, consent is undoubtedly the most practical legitimation of disclosure and those working in clinical genetics work hard to gain consent to disclosure. ${ }^{42}$ This may be facilitated through explanations and counselling prior to testing of the proband, and the

\footnotetext{
${ }^{35}$ Coco v AN Clark (Engineers) Ltd (1969) RPC 41 at 47; T Aplin et al Gurry on Breach of Confidence (Oxford: Oxford University Press, 2nd edn, 2012) para [1.02].

${ }^{36}$ A v B plc [2003] QB 195; Campbell v Mirror Group Newspapers Ltd [2004] 2 AC 457, HL.

${ }^{37}$ See for example Campbell v Mirror Group Newspapers, ibid, per Lord Nicholls and Baroness Hale; Douglas v Hello (No 3) [2006] QB 125, CA, at 161; McKennitt v Ash [2008] QB 73, CA, at 82 and 86; Hutcheson v News Group Newspapers Ltd [2011] EWCA Civ 808 at [22] and [39].

${ }^{38}$ Although compare the refusal to recognise forensic genetic information as personal and private by the House of Lords in $R$ (on the application of S) $v$ Chief Constable of South Yorkshire; $R$ (on the application of Marper) $v$ Chief Constable of South Yorkshire [2004] UKHL 39; cf the European Court of Human Rights in S v United Kingdom (30562/04); Marper v United Kingdom (30566/04) (2009) 48 EHRR 50.

${ }^{39}$ [2000] 1 WLR 515 at 527 (Lord Philips MR, citing Rougier J's High Court judgment in the case).

${ }^{40} Z$ v Finland (22009/93) (1998) 25 EHRR 371; I v Finland (2009) 48 EHRR 31; Ashworth Hospital Authority v MGN Ltd [2002] UKHL 29; McKennitt $v$ Ash, above n 37; Aplin, above n 35, para [6.122].

${ }^{41}$ W v Egdell [1990] Ch 359.

${ }^{42}$ Consent in genetics is a highly controversial area, and the subject of extensive literature. For the purposes of our argument, however, we do not delve into these issues, which have been explored in depth by others. Instead, we note that courts regularly address the question of whether consent is present as a matter of fact, and where necessary would be entirely capable of making such findings of fact in relation to the duty of confidence.
} 
use of follow-up counselling. Clinical genetics professionals may also attempt to circumvent strained family relationships through offers to convene meetings, provision of appropriate letters for the proband to distribute to family or offers to communicate with other HCPs (including GPs) where this might help facilitate disclosure. ${ }^{43}$ Despite the complications in practice, as a matter of law the question of consent is largely uncontroversial - consent will either be present or absent, and will be a question of fact in a particular case. ${ }^{44}$

In contrast, however, the question of disclosure in the public interest is more complex. The equitable duty of confidence is traditionally seen as a balancing of two competing public interests: the public interest in the maintenance of confidence on the one hand; and the public interest in disclosure on the other. ${ }^{45}$ Similarly, an Article 8 analysis requires the balancing of competing interests to determine whether disclosure is in the public interest. ${ }^{46}$ The cases on disclosure in the public interest in medical law can be characterised as falling into three broad categories: prevention of harm to others; prevention or detection of crime; and teaching, research or audit. ${ }^{47}$ It is only the first of these categories which will be of relevance to an HCP wishing to disclose genetic information to a third party member of the family of the proband.

The paradigm English case about disclosure in the public interest is $W v$ Egdell. ${ }^{48}$ The plaintiff, who was suffering from paranoid schizophrenia, shot and killed five people and injured two others in 1974. His plea of guilty to a charge of manslaughter was accepted, and he was detained in a psychiatric hospital. In support of his application for a transfer to a regional secure unit some 12 years later, the plaintiff sought a report from the defendant as an independent consultant psychiatrist. The defendant's report did not support the plaintiff's application; it disclosed that the plaintiff had a long standing and continuing interest in homemade bombs, and did not accept the view that the plaintiff was no longer a danger to the public. The plaintiff withdrew his application to the tribunal and refused to consent to the defendant disclosing the report to the medical officer at the secure hospital. However, the defendant disclosed the report without consent to the medical officer of the psychiatric hospital. On discovering the disclosure, the plaintiff sued for breach of confidence. It was held that whilst a duty of confidence was owed, and that maintenance of the duty of confidence was a matter of public interest, the public interest in maintaining the confidence (so that patients can trust their HCPs) must be balanced against the public interest in favour of disclosure (to the protect the public). Disclosure was justified in this case. The court held that what was required to justify disclosure in the public interest was a real, and not merely theoretical, risk of imminent and serious harm.

Other cases on disclosure in the public interest are few. Virtually all other cases have been about the disclosure of private information in the press, and the focus has rather been on the balancing of the public interest in the maintenance of confidentiality or privacy against public interest in disclosure pursuant to the Article 10 right to freedom of expression. ${ }^{49}$ In Stone ${ }^{50}$ the court considered the application of Article 8 to the question of whether it was in the public interest to disclose the private medical information about a convicted murderer in the context of a report into the failures of the system of psychiatric and social care. The court held that the balance was in favour of disclosure, and was particularly influenced by the fact that the publicity and need for the report arose out of the criminal

\footnotetext{
${ }^{43} \mathrm{M}$ Parker Ethical Problems in Genetics Practice (Cambridge: Cambridge University Press, 2012); Dheensa, Fenwick and Lucassen, above n 16.

${ }^{44}$ For examples of determination of whether consent is present as a question of fact, see for example Al Hamwi vohnson [2005] EWHC 206 (QB); Lybert v Warrington Health Authority [1996] PIQR 45.

${ }^{45} W v$ Egdell, above $\mathrm{n} 41$, at 415.

${ }^{46}$ Z v Finland (1997) 25 EHRR 371; Stone v South East Coast Strategic Health Authority [2006] EWHC 1668 (Admin) at [26].

${ }^{47}$ E Jackson Medical Law (Oxford: Oxford University Press, 3rd edn, 2013).

${ }^{48} W v$ Egdell, above $\mathrm{n} 41$.

${ }^{49}$ Such as for example Campbell v Mirror Group Newspapers Ltd, above n 36; Douglas v Hello (No 3), above n 37, at 161; Hutcheson v News Group Newspapers Ltd, above n 37; PJS v News Group Newspapers [2016] UKSC 26.

${ }^{50}$ Stone $v$ South East Coast Strategic Health Authority, above n 46.
} 
acts of Mr Stone. This conclusion was reached solely in relation to Article 8, and was bolstered by reference to Article 10. Other cases which balance the Article 8 rights of individuals against the public interest draw more heavily on the public interest aspects of the Article 10 right to freedom of speech. ${ }^{51}$ Such Article 10 rights are unlikely to be engaged in the question of disclosure of genetic information to family members of the proband, so the case law provides little assistance.

\section{Balancing - relevant considerations}

The application of the law in this field to the disclosure of genetic information is complex. Egdell was a case where the requirements were all clearly satisfied on their facts - there was a real risk of serious physical harm, with a clear degree of imminence. Difficulties arise in the way in which the test can be applied in the genetic context, however, in all three aspects of risk, imminence and seriousness. Each of these considerations will need to be viewed in a more nuanced manner than in the typical scenarios in cases such as Egdell, where there was an imminent risk of serious criminal harm from a psychiatric patient.

The courts have traditionally viewed the duty of confidence as important and have been slow to find a public interest in disclosure in the absence of serious physical harm, or an Article 10 interest. It therefore seems plausible that for a disease which has an adult onset, with variable penetrance (such as for example BRCA breast cancer) that the traditional requirements would not be satisfied. This may sit uneasily with many clinicians, and potentially with the General Medical Council guidance on the duty of confidence. ${ }^{52}$

In light of Article 8 considerations, a more flexible view can and should be taken. In Stone, the court spoke of the need to examine the facts and circumstances of each case, and to adopt a 'close and penetrating examination'. ${ }^{53}$ Accordingly, a balance must be struck between the Article 8 rights of the proband, as against the Article 8 rights of the family members.

\section{Risk}

The court in Egdell spoke of a real, rather than merely theoretical, risk. In that case, the risk was seen to be real, although the person likely to manifest the risk was still in a secure unit, and unlikely to be released into the community for some time, and only after satisfying a number of other conditions set by various tribunals. The risk posed by genetic mutations should satisfy this criterion in many cases. There are two different ways that risk can be variable in genetics. First, as the familial closeness to the proband decreases, the risk decreases. For example, where a great-grandchild of a person with a neurodegenerative disease is concerned, there is a $12.5 \%$ risk of them carrying the mutation. ${ }^{54}$ Secondly, for diseases with variable penetrance, the risk of developing the disease may be lower. For example, some diseases have a high correlation between carrying a mutation and experiencing the disease. In other cases, other factors may influence whether the disease manifests, or whether it is serious or more minor, or the age of onset. All these factors may be taken into account by a court when considering the risk to others.

\section{Imminence}

In Egdell, the court attached some significance to the imminence of the harm in question - the potential release from a secure hospital, and ultimately into the community. Genetic diseases are rarely imminent, in the sense that harm will arise within hours or days. Many genetic diseases may be

\footnotetext{
${ }^{51}$ See for example Campbell v MGN [2004] UKHL 22.

${ }^{52}$ General Medical Council Confidentiality (2009).

${ }^{53}$ Stone $v$ South East Coast Strategic Health Authority, above n 46, at [34].

${ }^{54} \mathrm{Z}$ Stark et al 'Predictive genetic testing for neurodegenerative conditions: how should conflicting interests within families be managed?' (2016) 42 Journal of Medical Ethics 640.
} 
late onset, and the harm may arise many years into the future. However, medical interventions or screening may be possible at an early stage, and lifestyle changes can begin very early. In this sense, whilst the ultimate serious harm may not be immediate, some efforts to avert that harm may imminently be possible.

\section{Serious harm}

The question of whether harm is serious in the genetic context is also complex. Some cases may be clear, for example where the consequences of the disease are serious and there is an intervention possible. An instructive example is the case of a sudden cardiac death mutation where a defibrillator may be implanted, and/or medication may prevent sudden death, or the option exists to have increased screening or monitoring for early symptoms of the conditions (eg in Lynch syndrome which predisposes to various cancers). However, other genetic diseases, such as Huntington's disease are serious but have no (yet) known interventions. However, genetic medicine advances rapidly, and new treatments arise. To avoid disclosure now on the basis that there is no currently known treatment makes a decision frozen in time. Unless there is a means to regularly revisit decisions made on this basis, then there is a chance that someone is deprived of a chance to obtain treatment in the future, on the basis that their risk of inheriting the condition is not made known to them.

Even where there is no means to prevent a serious outcome such as death, there may be other steps which an individual might wish to take if they know about their risk. The opportunity to make reproductive choices is an obvious matter - including undertaking invasive testing of a pregnancy or seeking preimplantation genetic diagnosis to avoid passing on a familial condition. Other options include changing life choices, such as avoiding particular careers or doing things at a younger age to avoid missing out on opportunities if predisposed to a late onset condition.

In addition, harm could be constituted by the failure to know about carrier status, and thus passing on a genetic condition to a child. Would the balance be in favour of disclosure to relatives who could only be carriers, rather than having the condition themselves? Those individuals will not have serious health consequences themselves, but they would be able to use the information to make informed reproductive choices.

Arguably, the flexibilities inherent in the human rights (or indeed equitable) approach enable the court to take a more expansive view of harm. Accordingly, these types of harm which might be more problematic for a tort claim could be sufficient to justify disclosure in the public interest.

\section{Balancing of competing rights}

The balance in the case of disclosure to family members, in contrast to most of the cases in this field, is not between competing Article 8 and Article 10 rights, but rather competing Article 8 rights. The right in question is of one individual keeping medical information confidential, as against the right of another person to have access to information which is important for their private and family life. The courts will balance these rights taking into account all the circumstances, and cannot prioritise one person's convention right over another. Such balancing will necessarily be highly dependent on the facts of the case, and courts are ideally placed to weigh the relevant and competing factors, in conducting an 'ultimate' balancing exercise applying the proportionality test to the rights of each party. ${ }^{55}$

\section{Ethical duty vs legal duty?}

Whether HCPs have an ethical duty to disclose information to family members is the subject of extensive commentary and discussion in the bioethics literature. The dominant model is known as the joint account model, and was proposed by Parker and Lucassen in a paper in the British Medical Journal in

\footnotetext{
${ }^{55}$ In re S (a child) [2004] UKHL 47, [2005] 1 AC 593 at [17].
} 
$2004 .{ }^{56}$ In that paper, Parker and Lucassen argue that as genetic information is shared by more than one individual (like information about a joint bank account), the ethical problem faced by a clinician is not whether to respect confidentiality, but instead, 'what, if anything, would justify excluding others from the joint account'. They suggest that, on the joint account model, it is assumed that information should be made available to all account holders unless there are good reasons to do otherwise.

Since publication, the joint account model has been widely cited, and has been broadly adopted in bioethics literature. ${ }^{57}$ It has informed the guidelines from the Joint Committee on Medical Genetics about consent and confidentiality to the extent that the guidelines recommend a record of discussion form for genetic testing which includes a statement that 'I acknowledge that my results will sometimes be used to inform the appropriate healthcare of family members' rather than asking for agreement to sharing. ${ }^{58}$

The joint account model draws on a model of autonomy that is relational in nature. In contrast to more traditional conceptions of autonomy which underpin the focus on the individual in biomedical ethics, relational autonomy is increasingly being adopted as the basis of bioethical approaches, particularly with respect to the ethical, legal and social implications of genetics and genomics. A relational approach enables a more nuanced approach to ethical questions, with a focus on the development of individual autonomy through social embeddedness and relationships with others. ${ }^{59}$ Such an approach seems intuitively more attractive for questions about genetics, where relatedness, and relationships, are at the very core of the subject matter that gives rise to the ethical questions.

The extent to which the law of confidence can accommodate a strongly relational autonomy approach is unclear. As Foster and colleagues acknowledge, courts are unlikely to 'take on a completely relational approach to the law' ${ }^{60}$ It seems that the most appropriate means to do so is to incorporate considerations as to relatedness into questions of disclosure in the public interest. A wider conception of the public interest, which takes account of the relational nature of the information in question, seems possible and appropriate. Indeed, when balancing the public interest in press publication privacy cases, questions of the rights of children and other family members are balanced by the courts in weighing the public interest in maintence of confidentiality versus freedom of expression. ${ }^{61}$ An approach to autonomy which considers the individual as embeded within their social context and family relationships can be accommodated in this way.

What seems less workable is a broad adoption of the ethical joint account model as a legal model which sees the information in question as 'belonging' to all family members jointly. First, it is not clear who the information would be 'owned' by. As noted above, information has diminishing relevance to family members the further away from the proband they are in relatedness. However, there is still a chance that the information is relevant. As Liao notes, different types of genetic information will have stronger reasons to be shared with family members than others, due to the nature of disease inheritance. ${ }^{62}$ It seems unlikely that a broad conception of joint 'ownership' of genetic information

\footnotetext{
${ }^{56}$ Parker and Lucassen, above n 5, at 166.

${ }^{57}$ See for example S Dheensa, A Fenwick and A Lucassen, “'Is this knowledge mine and nobody else's? I don't feel that." Patient views about consent, confidentiality and information-sharing in genetic medicine' (2016) 42 Journal of Medical Ethics 174; S Dheensa et al 'Health-care professionals' responsibility to patients' relatives in genetic medicine: a systematic review and synthesis of empirical research' (2016) 18 Genetics in Medicine 290; B Godard et al 'Guidelines for disclosing genetic information to family members: from development to use' (2006) 5 Familial Cancer 103; A Davey, A Newson and P O'Leary 'Communication of genetic information within families: the case for familial comity' (2006) 3 Journal of Bioethical Inquiry 161.

${ }^{58}$ Dheensa, Fenwick and Lucassen, above n 57.

${ }^{59} \mathrm{~A}$ detailed discussion of relational autonomy is beyond the scope of this paper. For a consideration of the applicability of relational models of autonomy in genetics see inter alia $\mathrm{H}$ Widdows 'Between the individual and the community: the impact of genetics on ethical models' (2009) 28 New Genetics and Society 173.

${ }^{60} \mathrm{C}$ Foster, J Herring and M Boyd 'Testing the limits of the "joint account" model of genetic information: a legal thought experiment' (2015) 41 Journal of Medical Ethics 379 at 381.

${ }^{61}$ PJS v News Group Newspapers, above n 49.

${ }^{62} \mathrm{SM}$ Liao 'Is there a duty to share genetic information?' (2009) 35 Journal of Medical Ethics 306.
} 
would be in accordance with Article 8 obligations. Finally, treating genetic information in this exceptional manner seems unwarranted, as other health information (such as cholesterol levels) is private to the individual, whilst nonetheless having some relevance for family members. ${ }^{63}$

Interestingly, in research carried out into patient views on the sharing of genetic information with family members without consent, the patient views arguably aligned more with the law of confidence than the joint account model. ${ }^{64}$ Dheensa and colleagues found that the patients they studied found it generally acceptable that an HCP share information with family members without consent and that while they considered that this would indeed be a breach of confidence, that the 'harm was trivial compared with the benefit of knowing about the risk'. In our view, this approach broadly accords with the authorisation of disclosure of confidential information in the public interest, with the justification framed in terms of preventing illness that could lead to avoidable harm. ${ }^{65}$

The joint account model serves a useful purpose to facilitate discussion as to the nature of genetic information and the way in which it is practically treated in the clinical genetics context. To the extent that the joint account model reflects the true practice of clinical genetics (the 'law in practice') then it is essential that regard is paid to the congruence between it and the law. The joint account model usefully highlights the potential difficulties that can arise where there is familial conflict, and proposes an ethical approach to confidentiality and genetic information. It is not, however, a true reflection of the legal approach to genetic information and confidentiality, and to apply the joint account model as a justification for disclosure without regard to the legal duty of confidence would be potentially problematic and could lead to liability for breach of confidence.

Where there is no refusal to communicate, then both the legal approach and the joint account model are consistent: whether there is consent to disclosure and therefore no breach in the traditional model, or the information is part of the joint account, HCP, proband and third party will be satisfied as to their legal rights and responsibilities. The difficulties (as in all areas of law) arise at the margins, where conflict arises. In the type of case which concerns us in this paper, where the proband refuses either to consent to disclosure or to pass on the relevant information to third parties, the law and the joint account model seem likely to result in different outcomes.

\section{The duty to family members}

The duty of confidentiality is a duty owed to the proband. Those family members who may share genes with the proband are third parties: external to the confidential relationship. It is, as considered above, permissible in some circumstances to disclose information to third parties. However, no duty to a third party can arise under a duty of confidentiality.

In the absence of a confidential or contractual relationship between the HCP and the third party, a legal duty to disclose can only arise in tort: specifically, in negligence. A claim in negligence requires that the HCP owes a duty of care to the third party: without such a duty, the negligence claim fails at the first hurdle. The third party must also show that the HCP breached that duty by acting unreasonably, ${ }^{66}$ and that the breach caused the third party damage. ${ }^{67}$ Although damage, in the context of negligence, is usually restricted to physical injury, psychiatric injury in the form of a recognised mental illness, property damage and economic loss, it has also been held to include interference with the

\footnotetext{
${ }^{63}$ Although some HCPs would argue that information about cholesterol levels, at least when high enough to suggest a familial component, is information which should also be shared with family members, akin to genetic information.

${ }^{64}$ Dheensa, Fenwick and Lucassen, above n 57.

${ }^{65}$ Dheensa, Fenwick and Lucassen, above n 57.

${ }^{66}$ Bolam v Friern Hospital Management Committee [1957] 1 WLR 582; Montgomery v Lanarkshire Health Board, above $\mathrm{n} 29$.

${ }^{67}$ Barnett v Chelsea and Kensington Hospital Management Committee [1969] 1 QB 428.
} 
claimant's right to reproductive autonomy. ${ }^{68}$ Courts have also allowed negligence type claims to succeed on the basis of violation of the claimant's rights. ${ }^{69}$

While the Court of Appeal's judgment in $A B C$ opens the door to there being a duty imposed on HCPs to inform third parties of genetic information, there is as yet no authority that an HCP owes a general duty of care to any third party. However, as we argue below, third party duties have been imposed in a number of different areas, including psychiatric injury, ${ }^{70}$ wrongful birth, ${ }^{71}$ failure to protect from personal injury ${ }^{72}$ and causing economic loss. ${ }^{73}$ Our analysis of these cases concludes that both precedent and legal principle both support the imposition of a limited duty of care on HCPs, where they are aware of information that would seriously affect a third party. The duty would be to take reasonable steps to ensure that third parties who bear sufficient proximity to the patient and who will foreseeably be seriously affected are aware of the information.

We also consider whether, in the context of healthcare, it is necessary to use duty of care as a 'control mechanism', to keep the tort of negligence within acceptable bounds. We conclude that such a control mechanism is not justified in this context.

\section{The duty to warn}

A duty to warn is a duty to inform a claimant of information, which the defendant knew or should have known, which would have allowed the claimant to avoid harm. As far as English courts are concerned, a failure to warn is a 'pure omission" ${ }^{74}$ and there is no general duty for pure omissions in English tort law: unless there is a pre-existing duty of care, a person is not liable in negligence for a failure to warn. ${ }^{75}$ If applied to the clinical context, this would mean that an HCP is not liable for any failure to warn a non-patient, even if the omission causes easily preventable harm to that person. Prima facie, an HCP owes a duty of care to his patients, but not, under usual circumstances, to non-patients: until the HCP accepts a patient into his care, there is no duty of care. ${ }^{76}$

\section{Duties in tort to third parties}

When the case $A B C^{77}$ comes to trial, the claimant, as a third party to the doctor-patient relationship, will have to establish that the defendants owed a duty of care to her in the form of a duty to warn, which was co-existent with the duty owed to the primary party, her father. Co-existing duties are not unprecedented: in fact, there is no reason, either in legal principle or binding precedent, that such duties should not exist. ${ }^{78}$ The principle that a duty to one person - in contract or tort - excludes

\footnotetext{
${ }^{68}$ Rees v Darlington Memorial Hospital NHS Trust [2003] UKHL 52, [2004] 1 AC 309. See also Chester v Afshar [2004] UKHL 41, [2005] 1 AC 134, in which a 'modest departure from classical causation principles' (at [24]) was allowed in order to vindicate the claimant's right to autonomy.

${ }^{69}$ Van Colle v Chief Constable of Hertfordshire Police [2008] UKHL 50, [2009] AC 225; DSD v Metropolitan Police Commissioner [2015] EWCA Civ 646, [2016] QB 161; OOO v Commissioner of Police for the Metropolis [2011] EWHC 1246 (QB).

${ }^{70}$ McLoughlin v O’Brian [1983] 1 AC 410; Alcock v Chief Constable of South Yorkshire Police [1992] 1 AC 310.

${ }^{71}$ Rand v East Dorset Health Authority (2000) 56 BMLR 39.

${ }^{72}$ Perrett v Collins [1998] 2 Lloyd's Rep 255; Watson v British Boxing Board of Control [2001] QB 1134.

${ }^{73}$ White $v$ Jones [1995] 2 AC 207.

${ }^{74}$ Smith $v$ Littlewoods Organisation Ltd [1987] AC 241 at 271 (Lord Goff).

${ }^{75}$ Yuen Kun Yu v Attorney General of Hong Kong [1988] AC 175 at 192 (Lord Keith); Mitchell v Glasgow City Council [2009] UKHL 11, [2009] AC 874.

${ }^{76}$ Barnett $v$ Chelsea and Kensington Hospital Management Committee, above n 67, at 435 (Nield J); Capital \& Counties plc $v$ Hampshire County Council [1997] QB 1004 at 1035 (Stuart-Smith LJ).

${ }^{77}$ ABC $v$ St George's Healthcare NHS Trust, above $\mathrm{n} 1$.

${ }^{78}$ See R Mulheron Medical Negligence: Non-Patient and Third Party Claims (London: Routledge, 2010) for a comprehensive analysis of third party liability in the medical context. See also M Fay 'Negligence, genetics and families; a duty to disclose actionable risks' (2016) 16 (3-2) Medical Law International 115 for an analysis in the context of disclosure in the case of genetic information, based on $A B C$.
} 
a duty to a third party, if it ever was part of English law, ${ }^{79}$ was conclusively laid to rest by Donoghue v Stevenson. ${ }^{80}$ In that case, the contractual duty owed as a manufacturer to the buyer of the ginger beer did not prevent a duty of care being owed to the consumer.

Duties to third parties collateral to duties to primary parties exist in many other areas of negligence: there is a general duty on all of us not only not to injure our 'neighbours ${ }^{81}$ - those who are foreseeably affected by our acts - but also not to cause psychiatric harm to those bearing a close tie of love and affection to our neighbours. ${ }^{82}$ This applies in all contexts where physical injury is caused by negligence, including the medical context. ${ }^{83}$

Also in a medical context, it has been found that an HCP can owe a duty not to cause economic loss to a third party: in wrongful birth cases, damages have been awarded to both parents, ${ }^{84}$ despite there being no doctor-patient relationship between the HCP and the father.

Third party duties have also been held to exist in cases of economic loss: where a person owes a duty to one party, there are circumstances in which there will also be a duty to a third party who foreseeably suffers loss as a result of a breach of the duty to the first party. Perhaps the clearest example of this is the case of White $v$ Jones: ${ }^{85}$ in this case, solicitors negligently delayed attendance upon a client who had instructed them to redraft his will. Before the client was able to execute the new will, he died, with the results that the intended beneficiaries under the new will received no legacies. In the claim against the solicitors, the House of Lords held, 3-2, that the solicitors did owe a duty of care to the intended beneficiaries. This was based on the assumption of responsibility doctrine established in Hedley Byrne $v$ Heller. ${ }^{86}$ Two other cases ${ }^{87}$ also found that professionals owed a duty of care to third parties foreseeably affected by their negligence.

The White case significantly extended the reach of the assumption of responsibility approach to economic loss established in Hedley Byrne. Unlike Hedley Byrne and other cases in which a duty to a third party was found on the basis of assumption of responsibility, the claimants did not know that the defendants had been instructed, and therefore could not be relying on them to carry out their duty to the primary party: ' $[w]$ hat is important is not that A knows that B is consciously relying on A, but A knows that B's economic wellbeing is dependent upon A's careful conduct of B's affairs' ${ }^{88}$

The principle in White has been described by Witting ${ }^{89}$ as the 'extended Hedley Byrne' principle. ${ }^{90}$ The relevant elements of this principle have been set out as:

\footnotetext{
${ }^{79}$ Such a principle was upheld in the case of Winterbottom $v$ Wright (1842) 10 M\&W 109 at 115 (Lord Abinger CB): 'By permitting this action, we should be working this injustice, that after the defendant had done everything to the satisfaction of his employer, and after all matters between them had been adjusted, and all accounts settled on the footing of their contract, we should subject them to be ripped open by this action of tort being brought against him'. This was approved by Lord Tomlin in his dissenting judgment in Donoghue $v$ Stevenson [1932] AC 562.

${ }^{80}$ Donoghue $v$ Stevenson, above $\mathrm{n} 79$.

${ }^{81}$ Donoghue $v$ Stevenson, above n 79, at 580 (Lord Atkin).

${ }^{82}$ McLoughlin v O'Brian, above n 70; Alcock v Chief Constable of South Yorkshire Police, above n 70.

${ }^{83}$ Walters $v$ North Glamorgan NHS Trust [2002] EWCA Civ 1792; Farrell v Avon Health Authority [2001] All ER (D) 17 (Jul).

${ }^{84}$ Rand v East Dorset Health Authority (2000) 56 BMLR 39; McLelland v Greater Glasgow HA [2001] SLT 446; Farraj v King's Healthcare NHS Trust [2009] EWCA Civ 1203, [2010] 1 WLR 2139. See also Hibbert Pownall \& Newton $v$ Whitehead [2008] EWCA Civ 285, in which the father of a disabled child brought a claim in professional negligence against solicitors acting for the mother's estate, for failing to advise him that he might have a claim in his own right. The Court of Appeal appears to have accepted that, although the solicitors did not owe the father a duty as a third party, the doctors managing the pregnancy did.

${ }^{85}[1995] 2$ AC 207.

${ }^{86}[1964]$ AC 465.

${ }^{87}$ Smith $v$ Eric S Bush [1990] 1 AC 831 and Gorham v British Telecommunications plc [2000] 1 WLR 2129.

${ }^{88}$ White $v$ Jones, above $\mathrm{n} \mathrm{85}$, at 272 (Lord Browne-Wilkinson).

${ }^{89} \mathrm{C}$ Witting 'Duty of care: an analytical approach' (2005) 25(1) OJLS 33.

${ }^{90}$ The same term ('extended Hedley Byrne principle) has also been used judicially to describe the extension of Hedley Byrne to circumstances where the breach was caused other than by negligent statements: Williams v Natural Life Health Foods Ltd [1998] 1 WLR 830 at 834 (Lord Steyn).
} 
- comparative skill or expertise;

- actual knowledge;

- conscious decision to accept responsibility for primary ${ }^{91}$ party;

- tight causal connection. ${ }^{92}$

Applying these principles, a duty of care to a third party will arise: where a professional undertakes a duty to a primary party; that the defendant knows that breach will cause damage to a third party of the same type as the defendant is under a duty to prevent to the primary party; and there is no conflict between the interests of the primary and third parties. ${ }^{93}$ This, coupled with causal proximity, creates a duty of care.

The relationship in White, between a professional and the third parties who are both proximate to his client and liable to suffer damage through the professional's acts or omissions, applies directly to the relationship between the healthcare professional and those who are proximate to the patient.

A similar principle was stated by the Court of Appeal in Watson $v$ British Boxing Board of Control. ${ }^{94}$ Having found, on the basis of assumption of responsibility, that the governing body of boxing owed duty of care to boxers, they went on to state a wider principle:

These cases ${ }^{95}$ establish that, where A advises B as to action to be taken which will directly and foreseeably affect the safety or well-being of $\mathrm{C}$, a situation of sufficient proximity exists to found a duty of care on the part of A towards C. ${ }^{96}$

With this exception, the extended Hedley Byrne principle has been mainly applied to situations involving economic loss. However, that is a consequence of the principle being applied in circumstances where the duty to the primary party is to avoid economic loss, rather than physical injury. There is no reason that a duty for an HCP not to cause injury, by failing to warn, should not be founded on the same principle. Indeed, as a general principle, courts should be more ready to find a duty of care where the damage caused is physical rather than economic.

The contrasting approaches taken by the House of Lords in Marc Rich v Bishop Rock Marine ${ }^{97}$ and the Court of Appeal in Perrett $v$ Collins ${ }^{98}$ illustrate this principle: in both cases damage was caused to a third party by negligent inspection of the means of transport in question. However, when it was argued that the Court of Appeal should apply the same approach to physical injury as to economic loss, Hobhouse LJ held:

What the Second and Third Defendants seek to achieve in this case is to extend decisions upon 'economic' loss to cases of personal injuries. It represents a fundamental attack upon the principle

\footnotetext{
${ }^{91}$ Emphasis added: the Hedley Byrne principle requires the defendant to assume responsibility for the primary party. Under the 'extended Hedley Byrne principle', the duty to the third party arises without the defendant having consciously accepted responsibility for the third party.

${ }^{92}$ Witting, above $\mathrm{n} 89$, at $59-60$.

${ }^{93}$ See McLeod $v$ Crawford 2011 SCLR 133: White $v$ Jones failed on lack of fundamental community - widow had different interests; and Caliendo v Mishcon de Reya [2016] EWHC 150 (Ch), [725]: the solicitors' duty to a third party extended as far as the third party's interests were aligned with the solicitors' clients.

${ }^{94}$ [2001] QB 1134.

${ }^{95}$ Clay v AJ Crump \& Sons Ltd [1964] 1 QB 533; Marc Rich \& Co AG v Bishop Rock Marine Co Ltd [1996] AC 211; X (Minors) v Bedfordshire County Council [1995] 2 AC 633; Phelps v Hillingdon London Borough Council [2001] 2 AC 619; Perrett $v$ Collins [1998] 2 Lloyd's Rep 255.

${ }^{96}$ [2001] QB 1134, at [72] (Lord Phillips MR, giving the only judgment).

${ }^{97}$ [1996] 1 AC 211. A marine surveyor negligently allowed a ship, which later sank, to retain its classification. The House of Lords held that it would not be 'fair, just and reasonable' to hold the defendant liable to the cargo owners.

${ }^{98}$ [1998] 2 Lloyd's Rep 255. An aircraft inspector negligently issued a certificate of airworthiness. The aircraft crashed, causing physical injury to the plaintiff, a passenger. See also C Witting 'Negligent inspectors and flying machines' (2000) 59(3) CLJ 544.
} 
of tortious liability for negligent conduct which had caused foreseeable personal injury to others. That such a point should be considered to be even arguable shows how far some of the fundamental principles of the law of negligence have come to be eroded. ${ }^{99}$

A similar approach was endorsed by Lord Hoffmann in Customs and Excise Commissioners $v$ Barclays Bank plc, ${ }^{100}$ in which he held that:

In the case of personal or physical injury, reasonable foreseeability of harm is usually enough, in accordance with the principle in Donoghue $v$ Stevenson, ${ }^{101}$ to generate a duty of care. In the case of economic loss, something more is needed. ${ }^{102}$

Applying these principles to the doctor-patient relationship, it is clear that, in some circumstances, an HCP should owe a duty of care to third parties. As an example, consider the case of a paediatrician who negligently fails to diagnose a child with a contagious disease, such as meningitis, and allows her to return home. ${ }^{103}$ The ill child then infects a sibling before dying of the condition. The sibling suffers permanent brain damage. In these circumstances, there is no doubt that the paediatrician does owe a duty of care to the child's mother and father. ${ }^{104}$ If the shock of seeing her child die causes the mother to suffer a psychiatric illness, the paediatrician would be liable in negligence. It would clearly be 'fair, just and reasonable' for the paediatrician also to be liable to the sibling who contracted the disease and suffered personal injury.

Third party claims against HCPs are rare. In the case of West Bromwich Albion FC $v$ El-Safty, ${ }^{105}$ an orthopaedic surgeon had advised reconstructive surgery on a player's knee. The surgery was unsuccessful and the player was not able to play football: as a result, the football club lost his services while remaining liable for his wages. A claim by the footballer in negligence succeeded, with the surgeon admitting negligence. ${ }^{106}$ However, the claim by the football club failed: the Court of Appeal held that the surgeon did not owe a duty not to cause financial loss to the footballer's employers. As Rix LJ pointed out, unlike Gorham, there was no 'fundamental community' between the patient's interests and his employer's interests: the employee's interest was financial, while the patient's interest was medical. The 'fundamental community' requirement seems to be that the damage to the third party is either the same or of the same type as the defendant was under a duty not to cause to the primary party. In successful third party claims, ${ }^{107}$ the third party's interests coincided with the primary party's.

In general, third parties cannot recover for economic loss caused by physical injury caused to the primary party: ${ }^{108}$ however, if there is a duty not to cause physical injury, as exists in the doctor-patient relationship, the fundamental community requirement will be met and the third party should be able to recover for physical injury.

\footnotetext{
${ }^{99}$ [1998] 2 Lloyd's Rep 255 at 257-258 (Hobhouse LJ) (emphasis added).

${ }^{100}$ [2006] UKHL 28, [2007] 1 AC 181.

${ }^{101}$ Donoghue $v$ Stevenson, above $\mathrm{n} 79$.

${ }^{102}$ [2006] UKHL 28 at [31].

${ }^{103}$ In Evans $v$ Mayor of Liverpool [1906] KB 160, it was argued that hospitals did have a duty to protect family members from premature discharge of contagious patients: the plaintiff failed because the doctors had not breached their duty, but it seems to have been accepted that there was a duty to the family members who might be infected if the patient was discharged prematurely.

${ }^{104}$ McLoughlin v O'Brian, above n 70, at 422 (Lord Wilberforce); Alcock v Chief Constable of South Yorkshire Police, above n 70, at 397 (Lord Keith).

${ }^{105}$ [2006] EWCA Civ 1299, 92 BMLR 179.

${ }^{106}$ Appleton v El Safty [2007] EWHC 631 (QB).

${ }^{107}$ White v Jones [1995] 2 AC 207; Smith v Eric S Bush [1990] 1 AC 831; Gorham v British Telecommunications plc [2000] 1 WLR 2129.

${ }^{108}$ Best $v$ Samuel Fox [1952] AC 716; London Borough of Islington v University College Hospital NHS Trust [2005] EWCA Civ 596; Burgess v Florence Nightingale Hospital for Gentlewomen [1955] 1 QB 349 at 355 (Devlin J).
} 


\section{Duty as a control mechanism}

Duty of care is the preferred 'control mechanism' in negligence: by restricting the expansion of new duties of care, the courts have sought to control the proliferation of claims ${ }^{109}$ and to relieve defendants from indeterminate liability. As noted by Lord Nicholls in $D v$ East Berkshire Community Health NHS Trust: ${ }^{110}$

Abandonment of the concept of a duty of care in English law, unless replaced by a control mechanism which recognises this limitation, is unlikely to clarify the law. That control mechanism has yet to be identified. ${ }^{111}$

One of the principal areas in which duty of care has been used as a control mechanism has been when determining the liability of public authorities for 'pure omissions', such as failure to prevent physical injury caused by a third party or external causes. The courts have consistently held that there is no duty of care in those circumstances. Decided cases have included a failure of the police to arrest a serial murderer ${ }^{112}$ or persons who had threatened the claimant, ${ }^{113}$ failure of a local authority to warn a resident that his neighbour was likely to cause him harm, ${ }^{114}$ failure of a health authority to recognise that a patient under the care of a mental health team posed a danger to the public, ${ }^{115}$ and failure of the police to respond to a 999 call. $^{116}$

This restrictive approach is largely based on public policy arguments. ${ }^{117}$ In addition, where the claimant is a member of the general public, there will be no proximity between defendant and claimant: in the leading House of Lords case of Hill $v$ Chief Constable of West Yorkshire Police, ${ }^{118}$ the principal reason given by Lord Keith ${ }^{119}$ for not finding the police liable for injury caused by their failure to arrest a serial murderer was the lack of proximity between the police force and a member of the general public. There was nothing to distinguish Jaqueline Hill from any other young woman who might become the murderer's next victim. ${ }^{120}$ Similarly, in Palmer $v$ Tees Health Authority, ${ }^{121}$ there was insufficient proximity between the claimant, as a member of the general public with a young daughter, and the health authority that had failed to prevent her daughter's abduction and murder by treating or detaining the murderer.

The main policy issues considered by the courts in the context of third party claims have been the proliferation of claims ${ }^{122}$ and indeterminate liability ${ }^{123}$ considerations: these apply to claims against individuals, such as accountants, ${ }^{124}$ as well as public authorities. In the specific cases of claims against public authorities, the court has also cited the undesirability of encouraging defensive practices by

\footnotetext{
${ }^{109}$ The oft-cited 'floodgates'.

${ }^{110}$ [2005] UKHL 23, [2005] 2 AC 373.

${ }^{111}$ At [94]. See also White $v$ Chief Constable of South Yorkshire Police [1999] 2 AC 455 at [129] (Lord Hoffmann).

${ }^{112}$ Hill v Chief Constable of West Yorkshire Police [1989] AC 53.

${ }^{113}$ Osman v Ferguson [1993] 4 All ER 344; Van Colle v Chief Constable of Hertfordshire Police [2008] UKHL 50, [2009] AC 255.

${ }^{114}$ Mitchell v Glasgow City Council [2009] UKHL 11, [2009] AC 874.

${ }^{115}$ Palmer $v$ Tees Health Authority (1998) 45 BMLR 88.

${ }^{116}$ Michael $v$ Chief Constable of South Wales Police, above n 25.

${ }^{117}$ For analyses of the policy bases underpinning the liability of public authorities in negligence, see, for example, $\mathrm{S}$ Tofaris and S Steel 'Negligence liability for omissions and the police' (2015) 75(1) CLJ 128; A Robertson 'On the function of the law of negligence' (2013) 33 OJLS 31; A Robertson 'Policy-based reasoning in duty of care cases' (2013) 33(1) LS 119; S Bailey and M Bowman 'Public authority negligence revisited' (2000) 59 CLJ 85.

${ }^{118}$ [1989] AC 53.

${ }^{119}$ With whom Lords Brandon, Oliver and Goff agreed.

${ }^{120}[1989]$ AC 53 at 62 (Lord Keith).

${ }^{121}(1998) 45$ BMLR 88.

${ }^{122}$ See, for example, Customs and Excise Commissioners [2007] 1 AC 181 at [100] (Lord Mance); Smith v Littlewoods Organisation Ltd [1987] AC 241 at 280 (Lord Goff).

${ }^{123}$ Caparo v Dickman, above n 27, at 621 (Lord Bridge).

${ }^{124}$ Such as the defendant in Caparo v Dickman.
} 
public authorities, ${ }^{125}$ the undesirability of second-guessing non-justiciable decisions, such as those relating to the allocation of public resources, ${ }^{126}$ and distracting public authorities from their primary duties. ${ }^{127}$ In $A B C$, Nicol J made specific reference to policy arguments applicable to public authorities, including the defensive practice argument and to the potential conflict between the public interest and a duty of care owed to an individual ${ }^{128}$ when considering whether an HCP could owe a duty of care to a third party.

In the healthcare context, however, public authorities may be liable for omissions. In Kent $v$ Griffiths, ${ }^{129}$ the London Ambulance Service was found liable for a failure to attend within the promised time. The Court of Appeal held that a duty of care arose when the call was taken, and the defendant was liable for the damage caused by the failure of the ambulance to attend within a reasonable time.

On very similar facts, however, the Supreme Court held in Michael ${ }^{130}$ that no duty of care arose when the 999 call was made and accepted by the police. Kent was distinguished on the grounds that no promise to attend was made, so that there was no assumption of responsibility. ${ }^{131}$ However, the duty of care in Kent was not based on the promise to attend. The duty of care arose from the ambulance's place within the NHS, which provided services to individuals rather than to the public as a whole: ${ }^{132}$ as a result, the public policy argument against finding a duty of care was much weaker than when considering the police and fire services. ${ }^{133}$ Once the ambulance service had accepted the call, the duty of care arose, irrespective of any promises to attend. ${ }^{134}$ In Michael, had Kent been applied, the duty would have arisen when the call handler told the victim that the call would be passed onto the South Wales Police. ${ }^{135}$

\section{An alternative control mechanism: breach of duty}

In the context of clinical negligence, courts have used the 'Bolam test'136 and the test set out in Montgomery $v$ Lanarkshire Health Board ${ }^{137}$ as control mechanisms which have kept litigation within proper bounds. While Bolam remains the appropriate test for clinical negligence claims involving diagnosis or treatment, in Montgomery, the Supreme Court held that it should only be applied where the decision in question required solely medical expertise. ${ }^{138}$ In cases where the decision is non-medical, such as which of the risks inherent in a specific procedure should be disclosed, or whether genetic information should be disclosed, the Bolam test is displaced by a requirement that the doctor should take reasonable care, as determined by the court. ${ }^{139}$ This would be the appropriate test to apply when determining whether an HCP was negligent in not disclosing information to a third party.

\footnotetext{
${ }^{125}[1989]$ AC 53 at 63 (Lord Keith).

${ }^{126} X$ (Minors) $v$ Bedfordshire County Council [1995] 2 AC 633 at 737-738 (Lord Browne-Wilkinson).

${ }^{127}$ Calveley and Others $v$ Chief Constable of Merseyside Police [1989] AC 1228 at 1238 (Lord Bridge); Brooks $v$ Commissioner of Police of the Metropolis [2005] UKHL 24, [2005] 1 WLR 1495 at [30] (Lord Steyn).

${ }^{128}$ ABC $v$ St George's Healthcare NHS Trust, above $\mathrm{n}$ 1, at [26].

${ }^{129}$ [2001] QB 36.

${ }^{130}$ Michael $v$ Chief Constable of South Wales Police, above n 25.

${ }^{131}$ At [138] (Lord Toulson).

${ }^{132}$ See T Nagel 'Ruthlessness in public bodies' in T Nagel Moral Questions (Cambridge: Cambridge University Press, 1979) ch 6 for an analysis of the different moral standards applicable to public bodies and private individuals, and the application of this analysis in R Mullender 'Negligence, public bodies, and ruthlessness' (2009) 72(6) MLR 961 to claims in negligence against public authorities.

${ }^{133}$ [2001] QB 36 at [45] (Lord Woolf, with whom Aldous LJ and Laws LJ agreed).

${ }^{134}$ At [49].

${ }^{135}$ See para [9] of the judgment.

${ }^{136}$ Bolam, above n 60; Bolitho $v$ City \& Hackney Health Authority [1998] AC 232.

${ }^{137}$ Montgomery $v$ Lanarkshire Health Board, above n 29.

${ }^{138}$ Montgomery $v$ Lanarkshire Health Board, above n 29, at [85] (Lords Kerr and Reed JJSC, with whom the other Justices of the Supreme Court agreed).

${ }^{139}$ Ibid, at [83].
} 
By placing the control mechanism at the breach, rather than at the duty stage, courts have been able to maintain a balance: protecting HCPs from indeterminate liability and not encouraging defensive medicine while at the same time recognising that 'the rule of public policy which has first claim on the loyalty of the law' is that wrongs should be remedied. ${ }^{140}$

\section{The duty of care in the medical context}

In the medical context, the reasons to hold that there is no duty to a third party fall away: the public policy reasons do not apply with such force; and duty of care is not needed as a control mechanism. As a result, the arguments against finding that an HCP might owe a third party - such as a first order relative of the proband - a duty of care become correspondingly weaker.

In the case of psychiatric injury caused by witnessing a traumatic event, the courts have developed a set of criteria, based on proximity and foreseeability and whether it is fair, just and reasonable to impose a duty, ${ }^{141}$ which limit the extent of the duty. ${ }^{142}$ By analogy, the duty to disclose information could be similarly limited by the courts to, for example, first and second order relatives, or those living in the same household. As has been recognised by the courts, such limits may be arbitrary, but are necessary to limit the scope of the tort and to protect defendants from indeterminate liability. ${ }^{143}$

In this context, proximity would depend upon the relationship - domestic or genetic - between the primary party and the third party. So an HCP might owe a duty to warn of an infectious disease to the persons living with the patient, as primary party, but not to visitors to the household or members of the general public. An HCP who negligently discharged a patient who was still infectious might owe a duty of care to that patient's immediate family, but would not be liable for a general outbreak of the disease. Applying the concept of proximity to the case of genetic conditions, the HCP might owe a duty to first and second order relatives, but not to more distant relations. This requirement would allay any fears of an HCP facing indeterminate liability as a result.

To succeed, the claimant would still have to show that the HCP did not act reasonably. The existence of a duty of care does not mean that the HCP is liable for any harm caused: he will only be liable to the extent that his failure to act reasonably caused the injury. So an HCP treating a genetic disorder would owe a duty to any relative with the necessary genetic proximity. But to hold the HCP liable for any harm suffered, the relative would also have to show that he acted unreasonably. As the Superior Court of New Jersey held in Safer $v$ Pack, the duty is to ensure 'that reasonable steps be taken to assure that the information reaches those likely to be affected or is made available for their benefit'. ${ }^{144}$

Depending on the specific circumstances, an HCP might discharge his duty to any relative by appropriate advice to the patient: for example, advising the patient of the risk to relatives and referring him to genetic counselling. If the HCP was aware that the patient was unwilling to pass on the information, then they might be under a duty to pass on the information, with the consequential breach of the patient's confidentiality, to any third parties with sufficient proximity to give rise to a duty of care.

Imposing such duties would not, as was suggested by counsel for the defendant in $A B C,{ }^{145}$ place HCPs in a difficult position, or at least no more than their existing professional obligations do.

\footnotetext{
${ }^{140}$ M (A Minor) $v$ Newham London Borough Council and X (Minors) v Bedfordshire County Council [1995] 2 AC 633 at 663 (Sir Thomas Bingham MR).

${ }^{141}$ Caparo v Dickman, above n 27.

${ }^{142}$ Alcock $v$ Chief Constable of South Yorkshire Police, above $\mathrm{n} 70$.

${ }^{143}$ See, for example, comments by Lord Oliver in Alcock at 417; and by Lord Goff, dissenting, in White $v$ Chief Constable of South Yorkshire Police [1999] 2 AC 455 at 488.

${ }^{144}(1996) 291$ NJ Sup 619, 677 A2d 1188 at 1192. This passage was quoted, with approval, by the Court of Appeal in $A B C v$ St Georges Healthcare NHS Trust, above n 2, at [59] (Irwin LJ).

${ }^{145} A B C$ v St George's Healthcare NHS Trust, above n 1, at [13].
} 


\section{Drawing together the duty of confidence and the duty to warn}

These two duties are the corollary of each other; in practice, questions about whether to disclose information to family members of a proband raise the issue of both the duty of confidence, and duty of care to third parties. But although the facts will be the same, the legal tests are separated, and approached differently depending on whether they are analysed from the point of view of the proband (duty of confidence) or that of the family member (duty to warn). Thus, the HCP at the heart of the matter will be faced with two potentially conflicting duties. It would be problematic if the application of the two legal tests led to conflicting outcomes.

At present, an analysis of the duty of confidence may result in a conclusion that disclosure to third parties is in the public interest. Unless there is at least a limited duty to warn in certain circumstances, as outlined above, a risk averse HCP would be well advised to maintain confidentiality, as there will be no party with standing to sue for breach of duty to warn, but there will be a party with a potential cause of action for breach of confidence. Such a position will, it is submitted, skew practice too far in favour of confidentiality.

If the balance of the law is as argued above, then the outcomes of the application of the tests of duty of confidence and the duty of care will be consistent, as well as congruent with ethical obligations. In determining whether disclosure is either authorised (duty of confidence) or required (duty of care) we suggest that ultimately, the HCP (or court) will be required to balance the competing rights of the parties, and that the central question that will be key in these cases is that of the harm that will result to the third party concerned.

Although there are conceptual differences between these tests, the relevant factors which will feed into the analysis are likely to be the seriousness of the genetic condition in question, its treatability and the chance that the relative in question might inherit the condition. An HCP will need to consider each factual situation on its merits. The question of the threshold of seriousness and treatability is the subject of significant debate in the genetics community, ${ }^{146}$ and HCPs will be able to draw on a body of professional opinion, ${ }^{147}$ which will no doubt also serve to inform a court.

Serious, treatable conditions will have greater impetus for disclosure than less serious, or untreatable conditions. For example, a case of sudden cardiac death, with a clear genetic contribution, serious outcome and treatment in the form of medication or implantable defibrillator which allows the harm to be averted provides a good example where the balance is likely to be struck in favour of sharing. ${ }^{148}$ Conversely, a condition with unclear genetic inheritance or low penetrance, with variable severity and late onset is likely to be one where the balance is struck in favour of maintaining confidence.

There will, however, be situations where the balancing exercise is more complex. We suggest that the cases most likely to be difficult to resolve will revolve around questions of whether there is legally actionable harm. An example is where there is a serious condition, but where at present there is no known treatment to modify disease course. Whether the law will recognise the personal utility that a party may attach to the mere possession of information, in the absence of any 'use' in the medical sense, is questionable. It must also be balanced against the harm that could result from forcing information on a person against their wish to know - a violation of the ethical principle of the 'right not to know. ${ }^{149}$

Additionally, it is unclear whether the law would recognise harm in the loss of chance relating to reproductive autonomy. Prenatal testing, preimplantation genetic diagnosis or prenatal testing are all

\footnotetext{
${ }^{146}$ See for example S Kalia et al 'Recommendations for reporting of secondary findings in clinical exome and genome sequencing, 2016 update (ACMG SF v2.0): a policy statement of the American College of Medical Genetics and Genomics' (2017) 19(2) Genetics in Medicine 249.

${ }^{147}$ Although professional opinion is the subject of debate, consensus will grow within the community as these cases arise more frequently, and as professional guidelines are written.

${ }^{148}$ The authors acknowledge that the clinical picture is rarely uncomplicated and there is likely to be complexity associated with penetrance and variable expressivity.

${ }^{149} \mathrm{R}$ Andorno 'The right not to know: an autonomy based approach' (2004) 30 Journal of Medical Ethics 435.
} 
available to those who are aware they are carrying genetic mutations. However, whether the law would recognise a loss of chance in relation to these opportunities seems doubtful.

Arguments in favour of a more expansive view of harm seem more likely to be successful in the context of the duty of confidence, particularly by reference to a human rights analysis. Therefore, an HCP who chooses to disclose to a third party to avert harm of this nature may avoid liability. However, a third party who wishes to claim against an HCP for breach of a duty of care for failure to disclose will be unlikely to succeed due to the law of negligence's more restricted view of harm. It is our contention that this distinction in recovery reflects an appropriate balance - it provides freedom to an HCP who feels an ethical obligation to disclose, but does not impose liability for failure to disclose.

Applying the test outlined above in the cases of ABC v St George's and Smith $v$ Leicester is instructive. We suggest that in neither case would the duty of care we propose be found to be breached. In $A B C$, had the HCPs wished to breach their duty of confidence, they could have argued that disclosure was in the public interest, although the fact that there is no known treatment for Huntington's disease, and that it is known that relatively few people undertake predictive genetic testing would have made that argument finely balanced. However, in the case of the duty of care, it is submitted that, whilst a duty should be owed, that in this case there would be no breach of the standard of care by maintenance of confidence. This is due primarily to the fact that there is no available treatment for this adult onset condition.

It seems likely that the outcome of Smith would also be unchanged. While it would be for the court to determine whether there was sufficient proximity, in the form of the genetic relationship between the patient and the third party, for there to be a duty, the claimant was the second cousin of the patient in question. This is a 5th order genetic relationship, with only $3 \%$ of genetic material shared between the parties. It is likely that the court would find insufficient proximity between the parties for there to be a duty of care.

\section{Conclusion}

The ultimate analysis in genetic information sharing cases will in essence relate to the nature of the harm which arises due to the failure to disclose. The concept of harm is likely to be problematic in many cases, as the type of harm arising may not be recognised in law. However, this failure of the law to recognise some types of harm arising in genetic information sharing is appropriate. The ethical judgements in these cases are not clear cut, and reasonable HCPs, and lawyers, may disagree as to the appropriate outcome. In the absence of clear ethical consensus, it seems appropriate that the law should not mandate disclosure. The appropriate outcome is that only in fairly rare cases should there be a duty to disclose, and in a slightly wider series of cases will disclosure be authorised.

As was noted in Montgomery, '[u]nder the stimulus of the Human Rights Act 1998, the courts have become increasingly conscious of the extent to which the common law reflects fundamental values' ${ }^{150}$ These fundamental values underpin the medical profession's ethical principles and it is desirable that legal obligations reinforce, rather than conflict with, professional obligations. ${ }^{151}$ Most HCPs working in clinical genetics regard informing those who might be directly affected by their patients' genetic information as something that a reasonable HCP should do, and there is a significant body of medical literature examining the circumstances in which disclosure is ethically desirable. ${ }^{152}$ In some

\footnotetext{
${ }^{150}$ Montgomery $v$ Lanarkshire Health Board, above n 29, at [80] (Lords Kerr and Reed).

${ }^{151}$ Ibid at [93] (Lords Kerr and Reed); ABC v St Georges Healthcare, above n 2, at [31], [63] (Irwin LJ). See also Chico, above n 21.

${ }^{152}$ Clarke, above n 16; Dheensa, Fenwick and Lucassen, above n 57; RB Dugan et al 'Duty to warn at-risk relatives for genetic disease: genetic counselors' clinical experience' (2003) 119C American Journal of Human Genetics 27; BM Knoppers et al 'The emergence of an ethical duty to disclose genetic research results: international perspectives' (2006) 14 European Journal of Human Genetics 1170; WC Leung et al 'Results of genetic testing: when confidentiality conflicts with a duty to warn relatives' (2000) 321 BMJ (Clinical research edition) 1464.
} 
circumstances, where disclosing the genetic information would allow the relative to receive earlier treatment, they might regard that as outweighing their duty of confidentiality to their patient. An HCP who does disclose information to a family member in the face of opposition from their patient runs the risk of being liable for breach of confidence. To counterbalance this risk, it is our contention that, in limited circumstances, a duty of care should arise. This would make the law congruent with the GMC Guidance on Confidentiality in relation to disclosure of genetic information to family members, as well as the reported experience of many HCPs working in clinical genetics. It is our contention that this is an additional factor in favour of the rebalancing of the law we propose.

The familial nature of genetic information strains the individualistic approach of the law in relation to confidentiality and tort. However, the law is sufficiently flexible to accommodate scientific and medical realities. The law of confidence permits the disclosure of information in the public interest, and the flexibilities of the way in which public interest is interpreted permit disclosure in limited and appropriate circumstances. More controversially, we argue that, in certain limited circumstances, a duty of care should be owed by an HCP to third party family members. We contend that it is more suitable in this case for the limits on liability to arise at the stage of breach, rather than the duty of care imposition.

Cite this article: Hawkins N, Hughes-Davies T (2018). Striking a balance: resolving conflicts between the duty of confidentiality and duties to third parties in genetics. Legal Studies 38, 645-665. https://doi.org/10.1017/lst.2018.11 